\title{
PENINGKATAN AKTIVITAS SEL EPITEL PADA KASUS DENTURE STOMATITIS OLEH GEL Epigallocatechin gallate 0,5\%
}

\author{
Sintha Nugrahini \\ Bagian Prostodonsia Fakultas Kedokteran Gigi Universitas Mahasaraswati Denpasar \\ email: sintha_pramudhita@yahoo.com
}

\begin{abstract}
Complete denture wearing patients are often associated with the presence of denture stomatitis. Poor-fitting dentures may increase mucosal trauma. It cause pressure on the mucosa and create a mechanical irritation. Epigallocatechin gallate (EGCG), is a flavonoid class of polyphenols antioxidant that have been widely researched, proven to have anti-inflammatory effects and may improve wound healing. The objective of this study was to prove the potential role of EGCG promoting reepithelialization of oral mucosa wound healing. The study was a randomized Post Test Only Control Group Design experimental study. 32 male rats (Rattus norvegicus) were divided into 2 treatment groups. The control group were given placebo gel administration (CMC-Na) for 3 days, and the treatment groups were given EGCG Gel $0.5 \%$ for 3 days. On the $6^{\text {th }}$ day, mice were euthanized for tissue sampling and histological preparations, made by HE stainning. The data were analyzed using the Independent $t$-Test. The mean of epithelial cleft of treatment group $(549.25 \pm 217.094 \mu \mathrm{m})$ was lower than the control group $(1417.25 \pm 180.572 \mu \mathrm{m})$, it was statistically different. EGCG Gel $0.5 \%$ increase production of Transforming Growth Factor-beta 1 (TGF- $\beta 1)$ to stimulate migration and adhesion of epithelial cell. Thus, it is concluded that EGCG gel 0.5\% enhance reepithelialization on mucosa wound healing of Denture Stomatitis.
\end{abstract}

Keywords: Denture Stomatitis, EGCG, wound healing, reepithelialization

\section{PENDAHULUAN}

Denture Stomatitis adalah masalah yang sering terjadi pada pengguna gigi tiruan lepasan. Pada keadaan ini, mukosa mengalami inflamasi bahkan jika ditimbulkan oleh trauma akan membentuk suatu luka terbuka yang menimbulkan rasa tidak nyaman pada pasien.

Denture stomatitis merupakan respon radang dimana proses radang tersebut tergantung dari intensitas dan konsentrasi dari tekanan yang diterima oleh jaringan yang terlibat. ${ }^{1}$ Denture stomatitis juga dikenal dengan denture sore mouth dan prosthetic stomatitis. Pada keadaan ini terjadi radang pada mukosa yang kontak dengan gigi tiruan, terutama yang paling sering adalah mukosa palatal dan gingival. Frekuensi terjadinya Denture stomatitis sebesar $11-67 \%$, paling sering terjadi pada wanita dan prevalensinya meningkat pada usia lanjut. $^{2}$

Etiologi dari Denture Stomatitis (DS) meliputi berbagai faktor, antara lain: kebersihan gigi tiruan yang kurang baik, penggunaan gigi tiruan sepanjang malam, akumulasi plak pada gigi tiruan, dan infeksi jamur. Gigi tiruan yang tidak stabil dapat menimbulkan trauma pada mukosa, pada kondisi ini terbentuk luka mekanis pada permukaan mukosa. Material yang terkandung dalam protesa gigi tiruan dapat meningkatkan resiko terjadinya DS, misalnya monomer resin, hydroquinone peroxide, dimethyl-p-toluidine, atau methacrylate yang merupakan suatu oksidan. $^{3}$

Dekomposisi dari oksidan yang terdapat pada protesa gigi tiruan akan melepaskan spesies oksigen reaktif (ROS) yang mengandung elektron tidak berpasangan. ${ }^{4}$ Keberadaan ROS penting dalam fase penyembuhan luka karena berfungsi untuk mencegah infeksi bakteri, namun tingginya kadar ROS menginduksi kerusakan sel lainnya, menghambat migrasi sel, dan menimbulkan stress oksidatif pada jaringan yang terpapar. ROS akan mengaktivasi dan mempertahankan kaskade asam arakidonat yang akan memicu mediator inflamasi seperti prostaglandin dan leukotrien, sehingga proses inflamasi akan berkepanjangan dan penyembuhan luka menjadi tertunda."

Sistem pertahanan tubuh terhadap radikal bebas dapat dibagi dalam dua kelompok besar, yaitu: sistem pertahanan preventif dan sistem pertahanan melalui pemutusan rantai reaksi radikal. ${ }^{6}$ Dampak buruk dari radikal bebas hanya dapat dilawan dengan antioksidan, yakni senyawa pereduksi yang dapat mencegah oksidasi suatu molekul menjadi radikal bebas. ${ }^{7}$ Antioksidan adalah molekul yang dapat menetralkan radikal bebas dengan cara menerima atau mendonorkan satu elektron untuk menghilangkan kondisi elektron yang tidak berpasangan, sehingga menjadi molekul yang stabil. ${ }^{6}$

Epigallocatechin gallate (EGCG) merupakan flavonoid polifenol golongan flavonol yang banyak ditemukan pada teh hijau. Flavonoid, merupakan antioksidan yang efektif untuk inaktivasi radikal hidroksil dan peroksil sehingga dapat mencegah pembentukan ROS. Mekanisme antioksidan senyawa polifenol berdasarkan kemampuan mendonorkan atom hidrogen dan kemampuan mengikat ion-ion logam. ${ }^{6}$

Katekin dari teh hijau dapat menghambat stres oksidatif pada jaringan yang mengalami inflamasi dan membantu meredakan proses inflamasi. ${ }^{8}$ EGCG menunjukan efek antiinflamasi dan antioksidan, dimana aplikasi topikal EGCG $0,5 \%$ pada kulit tikus dapat mengurangi kerusakan epidermal akibat radiasi ultraviolet. ${ }^{9}$ Pemberian EGCG secara topikal pada luka incisi, memiliki lebar bekas luka yang relatif kecil dan jaringan granulasi mengandung sedikit sel inflamasi. Pada penelitian tersebut disimpulkan bahwa EGCG memiliki potensi tinggi dalam aktivitas penyembuhan luka, terutama pada konsentrasi yang lebih tinggi. ${ }^{10}$ 
Berdasarkan uraian di atas, perlu dilakukan penelitian lebih lanjut untuk mengetahui potensi gel EGCG dalam penyembuhan luka mukosa mulut akibat penggunaan gigi tiruan lepasan. Dalam penelitian ini, reepitelisasi perlu diamati karena merupakan parameter yang penting dalam penyembuhan luka.

\section{Denture Stomatitis (DS)}

Denture Stomatitis (DS) sering terjadi pada mukosa mulut terkait dengan penggunaan gigi tiruan lepasan. Secara klinis, jaringan lunak di bawah gigi tiruan menunjukan gejala radang. Penderita merasakan sakit dan sensasi terbakar. ${ }^{11}$

Beberapa faktor dapat menyebabkan DS, antara lain: gigi tiruan yang tidak stabil sehingga dapat menimbulkan efek traumatik yang kronis pada mukosa di bawahnya, gigi tiruan yang kurang bersih akibat akumulasi plak, dan stress yang menimbulkan aktivitas otot rongga mulut. ${ }^{12}$ Faktor predisposisi terjadnya DS antara lain: faktor sistemik (Fisiologis, disfungsi endokrin, defisiensi nutrisi, neoplasia, immunosupresi, penggunaan antibiotik spektrum luas, faktor lokal (penggunaan kortikosteroid, diet tinggi karbohidrat, penggunaan alkohol dan tembakau, hiposaliva, kebersihan rongga mulut yang buruk, dan penggunaan gigi tiruan sepanjang malam. ${ }^{11}$

DS diklasifikasikan menjadi 3 tipe, ${ }^{13}$ yaitu: Tipe I: Pin Point Hyperemia, inflamasi lokal dan ringan atau dapat disebabkan oleh trauma, Tipe II: Erythematous type, pada seluruh bagian mukosa yang ditutupi oleh gigi tiruan, Tipe III: Granular type, pada daerah palatum dan alveolar ridge.

Luka pada mukosa akibat gigi tiruan yang tidak stabil merupakan luka dengan tipe yang sama seperti ulkus traumatik yang ditimbulkan oleh trauma fisik. Ulkus ini menimbulkan rasa sakit, bentuk yang tidak beraturan dilapisi oleh membrane nekrotik dan dikelilingi batas kemerahan. Gambaran histologis dari ulkus menunjukan adanya permukaan lapisan epitel yang terputus dengan eksudat fibrin melapisi jaringan ikat di bawahnya (Gambar 1). ${ }^{12}$
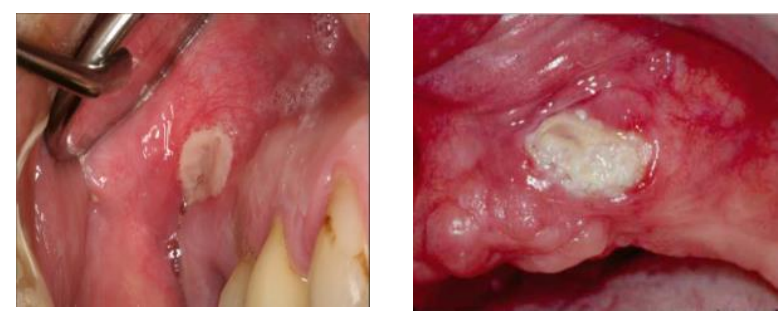

Gambar 1. Gambaran klinis Denture Stomatitis ${ }^{12}$

\section{Mukosa Mulut}

Jaringan lunak mulut terdiri dari mukosa pipi, bibir, gingiva, lidah, palatum, dan dasar mulut. Struktur jaringan lunak mulut terdiri dari lapisan tipis jaringan mukosa yang licin, halus, fleksibel, dan berkeratin atau tidak berkeratin. Jaringan lunak mulut berfungsi melindungi jaringan keras di bawahnya, tempat organ, pembuluh darah, saraf, alat pengecap dan alat pengunyah. Secara histologis jaringan mukosa mulut terdiri dari 3 lapisan, ${ }^{14,}{ }^{15}$ antara lain (Gambar 2): (1)Lapisan epitelium, yang melapisi di bagian permukaan luar, terdiri dari berlapis-lapis sel yang berbentuk pipih (datar) dimana lapisan sel-sel yang mati ini selalu diganti terus-menerus dari bawah, dan sel-sel ini disebut dengan stratified squamous epithelium atau epitel pipih berlapis. (2)Membrana basalis, yang merupakan lapisan pemisah antara lapisan ephitelium dengan lamina propria, berupa serabut kolagen dan elastis. Terdiri dari lamina lucida dan lamina densa. Pada (3)Lamina propria terdapat ujung-ujung saraf rasa sakit, raba, suhu. Kelenjar ludah yang halus terdapat di seluruh jaringan mukosa mulut. Lamina propria terdiri dari serabut kolagen, serabut elastin dan sel-sel fibroblas, makrofag, mast sel, sel inflamatori serta selsel darah yang penting untuk pertahanan melawan infeksi. Jadi mukosa ini menghasilkan sekret, bersifat protektif dan sensitif.

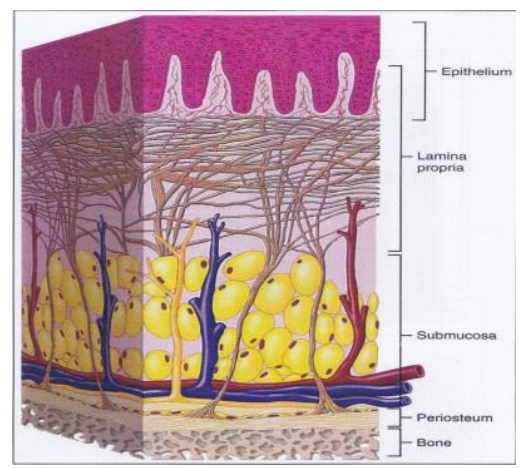

Gambar 2. Stuktur mukosa mulut. ${ }^{16}$

Luka akut atau kronis pada mukosa mulut sering terjadi. Luka tersebut disebut ulkus traumatik dapat terjadi akibat rangsangan mekanik, seperti kontak dengan benda yang tajam, tergigit selama mengunyah, trauma saat menyikat gigi, dan saat berbicara. Kerusakan mukosa mulut dapat terjadi karena iritasi bahan kimia, elektrik, rangsangan suhu, paparan radiasi, atau kolonisasi mikroorganisme. ${ }^{16}$

Pada pemeriksaan histologi, jaringan yang mengalami ulkus traumatik menunjukan kerusakan permukaan epitel, terdiri dari jaringan granulasi yang berisi sel inflamasi seperti limfosit, histiosit, neutrofil dan sel plasma (Gambar 3). ${ }^{17}$

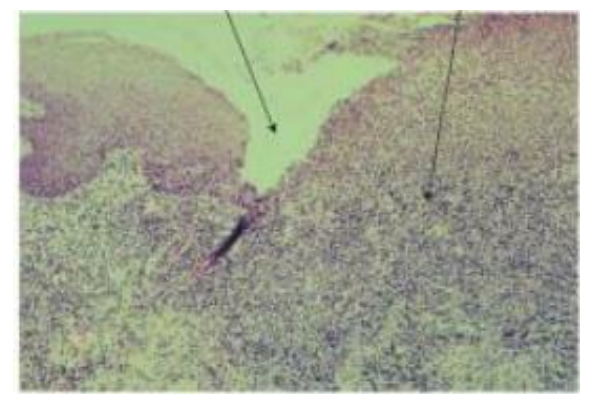

Gambar 3. Gambaran histologi ulkus traumatik: Kerusakan lapisan epitel; Infiltrasi sel-sel radang limfosit, neutrofil, histiosit dan sel plasma. ${ }^{17}$

Penyembuhan Luka Mukosa Mulut

Penyembuhan luka adalah reaksi dari organisme untuk mengembalikan kontinuitas dan fungsi dari 
jaringan atau organ yang mengalami jejas. ${ }^{18,19}$ Penyembuhan luka merupakan proses yang dinamis, dan melibatkan aktivitas beberapa macam sel dan matriks ekstraseluler dimana proses ini tergantung pada faktor lokal dan sistemik. Tujuan utama pada penyembuhan luka setelah terjadi jejas adalah untuk mengembalikan kontinuitas dan fungsi jaringan. Jejas dapat menyebabkan kerusakan pada pembuluh darah dan ekstravasasi sel darah. Proses penyembuhan luka dapat dibagi dalam tiga fase, yaitu fase inflamasi, fase proliferasi dan fase remodeling. ${ }^{18}$

Penyembuhan luka merupakan sebuah proses transisi yang merupakan salah satu proses paling kompleks dalam fisiologi manusia yang melibatkan serangkaian reaksi dan interaksi kompleks antara sel dan mediator. Fase inflamasi bertujuan untuk membuang jaringan mati dan mencegah infeksi. ${ }^{20}$ Tubuh memiliki respon fisiologis terhadap luka yakni proses penyembuhan luka. Proses penyembuhan luka terdiri dari berbagai proses yang kompleks untuk mengembalikan integritas jaringan (Gambar 4). Selama proses ini terjadi pembekuan darah, respon inflamasi akut dan kronis, neovaskularisasi, proliferasi sel hingga apoptosis. Proses ini dimediasi oleh berbagai sel, sitokin, matriks, dan growth factor. ${ }^{7}$

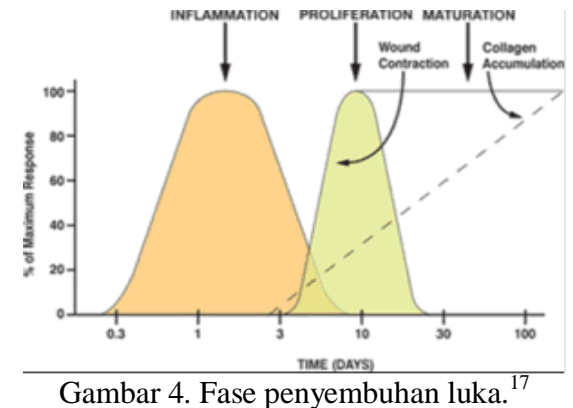

Fase Proliferasi dimulai hari ke dua setelah trauma jaringan dan berlanjut dua sampai tiga minggu setelah trauma. ${ }^{18}$ Fase proliferasi ditandai dengan terbentuknya jaringan granulasi yang disertai kekayaan jaringan pembuluh darah baru, fibroblas, dan makrofag dalam jaringan penyangga yang longgar. ${ }^{20}$ Fase ini disebut fase fibroplasia atau fase regenerasi, merupakan kelanjutan dari fase inflamasi ditandai dengan proliferasi dan migrasi fibroblas, serta produksi jaringan ikat. Terdapat tiga proses utama dalam fase proliferasi, antara lain reepitelisasi. Secara simultan, sel-sel basal pada epitelium bergerak menuju daerah luka dan menutupi daerah luka. ${ }^{18}$ Pada tepi luka, keratinosit akan berproliferasi setelah kontak dengan ECM dan kemudian bermigrasi dari membran basal ke permukaan yang baru terbentuk. Ketika bermigrasi, keratinosit akan menjadi pipih dan panjang dan juga membentuk tonjolan sitoplasma yang panjang. Pada ECM, mereka akan berikatan dengan kolagen tipe I dan bermigrasi menggunakan reseptor spesifik integrin. Kolagenase yang dikeluarkan keratinosit akan mendisosiasi sel dari matriks dermis dan membantu pergerakan dari matriks awal. Keratinosit juga mensintesis dan mensekresi Matrixmetalloproteinase lainnya ketika bermigrasi. ${ }^{21}$
Antioksidan Dalam Penyembuhan Luka

Antioksidan merupakan senyawa pemberi elektron atau reduktan. Senyawa ini memiliki berat molekul kecil, tetapi mampu menginaktivasi berkembangnya reaksi oksidasi, dengan cara mencegah terbentuknya radikal bebas. Antioksidan juga merupakan senyawa yang dapat menghambat reaksi oksidasi, dengan mengikat radikal bebas dan molekul yang sangat reaktif. akibatnya, kerusakan sel dapat dihambat. ${ }^{22}$ Stres oksidatif adalah suatu ekspresi yang digunakan untuk menyatakan proses kerusakan dalam tubuh akibat ketidakseimbangan atara pembentukan ROS yang berlebihan dengan jumlah oksidan yang terbatas jumlahnya. Antioksidan merupakan molekul yang dapat menetralkan radikal bebas. dan mencegah terjadinya stress oksidatif. ${ }^{7}$

EGCG mempunyai aktivitas antioksidan. Telah banyak penelitian ditujukan untuk menguji kekuatan antioksidan khususnya EGCG secara in vitro dan dilakukan pada binatang menunjukkan sifat sebagai antimutagenik, antidiabetik, antiinflamasi, antibakterial dan antivirus. ${ }^{17}$<smiles>CC(C)(F)C(=O)OCC(=O)Oc1cc(C(=O)O[C@H]2Cc3c(O)cc(O)cc3O[C@@H]2c2cc(O)c(O)c(O)c2)cc(O)c1O</smiles>

Dalam melindungi tubuh terhadap pengaruh oksidan, EGCG bekerja secara menyeluruh. Zat aktif ini dapat menembus hingga ke dalam sel untuk melindungi mitikondria dari kerusakan yang diakibatkan gugus hidroksil yang sangat reaktif (Gambar 5). Polifenol EGCG dapat melawan radikal bebas yang menyebabkan peradangan, mencegah oksidasi radikal bebas pada DNA, dan menghentikan pertumbuhan sel abnormal (kanker). ${ }^{17}$

\section{Peran Epigallocatechin Gallate (EGCG) dalam} penyembuhan luka

Spesies oksigen reaktif (ROS), memiliki efek buruk terhadap sel dan jaringan, sehingga dapat mempengaruhi proses penyembuhan luka. Stress oksidatif berimplikasi pada berbagai proses degeneratif dan terjadinya penyakit termasuk kondisi inflamasi akut maupun kronis seperti penyembuhan luka. Antioksidan memiliki peran penting dalam proses penyembuhan luka dengan mempercepat penyembuhan luka dan melindungi jaringan dari kerusakan oksidatif. ${ }^{10,23}$

Penyembuhan luka berkaitan dengan stress oksidatif, sehingga menghambat proses remodeling jaringan. Epigallocatechin gallate (EGCG) 10 ppm yang diberikan dalam busa kolagen (collagen sponge) dapat menurunkan ukuran luka pada tikus lebih cepat secara signifikan. Pemberian EGCG meningkatkan derajat epitelisasi pada luka diabetikum, penebalan jaringan granulasi dan densitas kapiler. ${ }^{24}$ 
Lapisan epitel pada mukosa mulut merupakan barier yang penting bagi organisme terhadap lingkungannya, melindungi dari kerusakan yang disebabkan oleh gangguan fisik, kimia dan mikroorganisme. Proses reepitelisasi setelah terjadinya luka pada mukosa merupakan peristiwa yang penting untuk mengembalikan fungsinya. Pada fase proliferasi, fibroplasia terjadi bersamaan dengan revaskularisasi dimana $T G F-\beta$ merupakan salah satu mediator yang menstimulus neovaskularisasi sehingga terbentuk pembuluh darah baru. Sementara proses tersebut terjadi, epitel permukaan di bagian tepi luka mulai melakukan regenerasi (reepitelisasi), sel-sel epitel mulai bermigrasi di atas permukaan luka dan berproliferasi. ${ }^{15}$

Proliferasi dan diferensiasi sel epitel dipengaruhi oleh beberapa sitokin antara lain: Epidermal growth factor (EGF), keratinocyte growth factor, dan TGF- $\beta 1$ yang merupakan faktor pertumbuhan penting dalam reepitelisasi. ${ }^{31}$ EGCG menunjukan efek antiinflamasi, meningkatkan reepitelisasi melalui peningkatan kerja Transforming Growth Factor- beta 1 (TGF- $\beta 1$ ), yang merupakan faktor utama untuk merangsang proliferasi fibroblas, produksi kolagen, kontraksi luka, dan ekspresi Connective Tissue Growth Factor (CTGF) ${ }^{11,25}$

TGF- $\beta 1$ menstimulasi migrasi dan meningkatkan kekuatan adhesi sel-sel epitel. 24 jam pertama setelah luka, sel-sel epitel di daerah tepi luka melepaskan perlekatannya dengan hemidesmosom dan memulai migrasi. Proliferasi dimulai pada leading edge kemudian sel-sel epitel mulai menyebar ke daerah luka. Sel-sel epitel bermigrasi sepanjang matriks yang dibentuk oleh fibrin-fibronektin sampai sel-sel tersebut saling terhubung dengan tepi luka sisi lainnya. ${ }^{24}$

\section{BAHAN DAN METODE}

Gel EGCG didapat dari Sigma-Aldrich, dibuat dalam sediaan mukoadhesif gel 0,5\% sebanyak 2 gr.

Rancangan penelitian yang digunakan adalah penelitian eksperimental dengan Randomized Post Test Only Control Group Design. ${ }^{25}$ Skema rancangan penelitian (Gambar 6):

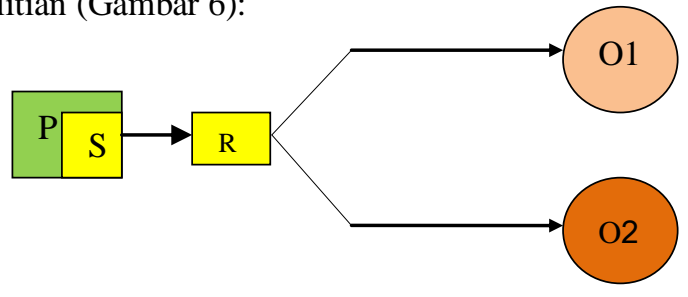

Gambar 6. Skema rancangan penelitian

Kelompok kontrol (16 ekor) dan kelompok perlakuan (16 ekor) dibuat luka menggunakan punch biopsy diameter $5 \mathrm{~mm}$ pada mukosa labial. Pemberian bahan obat dilakukan mulai pada hari ke dua. Kelompok kontrol diolesi gel placebo (CMC-Na) selama 3 hari. Kelompok perlakuan diolesi gel EGCG $0,5 \%$ selama 3 hari. Pada hari ke 6 semua hewan percobaan dieutanasia menggunakan eter secara inhalasi dan jaringan luka pada mukosa labial rahang bawah diambil.

Spesimen mukosa labial rahang bawah yang telah diambil, difiksasi dengan Neutral Buffer Formalin (NBF) 10\% dan dibuat sediaan mikroskopis. Untuk semua spesimen, pemotongan dengan mikrotom dilakukan dengan ketebalan 5 mikron, diambil untuk diwarnai dengan Harris Hematoxcylin Eosin. Perbandingan antar kelompok dilakukan dengan pemeriksaan mikroskopik dengan mengamati reepitelisasi dilihat pada potongan melintang luka mukosa labial mulut, yang telah dibuat preparat/sediaan mikroskopis dan dilihat pada 4 lapang pandang menggunakan mikroskop elektrik merk Olympus CX21 dengan pembesaran 400x. Reepitelisasi ditentukan dengan mengukur lebar celah epitel yang masih terbuka menggunakan metoda morfometri dengan satuan mikrometer. Pemotretan menggunakan videophoto dengan tiga kali pengulangan.

Pada penelitian ini dibandingkan dua kelompok (kelompok kontrol 6 hari dengan kelompok perlakuan 6 hari) pada hari yang sama, untuk membandingkan rerata reepitelisasi. Data yang diperoleh berdistribusi normal, sehingga digunakan uji statistik parametrik yaitu Independent T-test.

\section{HASIL DAN PEMBAHASAN}

Tabel Hasil analisis kemaknaan dengan uji independent $t$-test Reepitelisasi $(\mu \mathrm{m})$ mukosa mulut antar kelompok $(\mathrm{n}=16)$

\begin{tabular}{cccccc}
\hline $\begin{array}{c}\text { Kelompok } \\
\text { Subjek }\end{array}$ & $\begin{array}{c}\text { Rerata lebar } \\
\text { celah epitel } \\
(\mu \mathrm{m})\end{array}$ & SB & $\begin{array}{c}\text { Beda } \\
\text { rerata }\end{array}$ & t & $p$ \\
\hline Kontrol & 1417,25 & 180,57 & & & \\
& & & 868,00 & 12,29 & 0,001 \\
EGCG & 549,25 & 217,09 & & & \\
\hline
\end{tabular}

Reepitelisasi dinilai berdasarkan lebar celah epitel. Hasil penelitian menunjukkan rerata lebar celah epitel kelompok kontrol labih tinggi daripada kelompok perlakuan (tabel). Analisis kemaknaan dengan uji independent $t$-test menunjukkan bahwa nilai $t$ memiliki p-value yang lebih kecil dari alpha. Dengan demikian terdapat perbedaan lebar celah epitel yang signifikan diantara dua kelompok yang dibandingkan $(\mathrm{p}<0,05)$.

Peningkatan reepitelisasi pada penelitian ini sesuai dengan penelitian yang dilakukan oleh Neves et al., yang menyimpulkan bahwa pemberian EGCG dapat meningkatkan neoformasi sel epitel pada luka. ${ }^{26}$ Pada penelitiannya, observasi yang dilakukan pada hari ke 6 menunjukan adanya perbedaan yang signifikan antara kelompok kontrol dan perlakuan dimana lebar celah epitel pada kelompok perlakuan pemberian EGCG lebih pendek dibandingkan kelompok kontrol. Meningkatnya reepitelisasi akan mempercepat proses penyembuhan luka. Epitelisasi yang baik ditandai dengan celah epitel yang tertutup sempurna akibat migrasi sel epitel yang terus terjadi sampai luka tertutup. ${ }^{26}$

Meningkatnya reepitelisasi pada kelompok yang diberikan EGCG dapat disebabkan karena EGCG mampu meningkatkan faktor pertumbuhan yang dibutuhkan dalam migrasi dan proliferasi sel epitel. Epigallocatechin gallate merupakan senyawa polifenol yang menunjukkan efek antiinflamasi dan antioksidan sehingga mampu meningkatkan penyembuhan luka melalui peningkatan kerja Transforming Growth Factorbeta 1 (TGF- $\beta 1$ ). TGF- $\beta 1$ menstimulasi migrasi dan meningkatkan kekuatan adhesi sel-sel epitel, ${ }^{31}$ 
meningkatkan aktivitas enzim, menginduksi sintesis nitric oxide dan COX-2 yang diperlukan pada proses reepitelisasi luka. ${ }^{27}$

Pada penelitian ini, terdapat peningkatan reepitelisasi yang signifikan pada kelompok yang diberikan gel EGCG 0,5\%. Hal ini membuktikan bahwa EGCG dapat meningkatkan regenerasi sel epitel yang signifikan pada kelompok perlakuan. ${ }^{28}$ Berdasarkan penelitian tersebut, disimpulkan bahwa EGCG dapat mempercepat penyembuhan luka. Peningkatan reepitelisasi pada penelitian ini dapat disebabkan karena potensi EGCG sebagai antioksidan dalam mencegah terbentuknya radikal bebas yang dihasilkan oleh monomer methacrylate. ${ }^{3}$ Telah diketahui bahwa tingginya kadar ROS dalam jaringan akan menghambat migrasi sel dan menimbulkan stres oksidatif pada jaringan. EGCG mencegah terjadinya penundaan fase proliferasi penyembuhan luka akibat radikal bebas dan meningkatkan regenerasi jaringan untuk mengembalikan integritasnya. EGCG juga mempercepat proses inflamasi dan mengatur respon seluler terhadap luka berjalan dengan normal. ${ }^{30}$
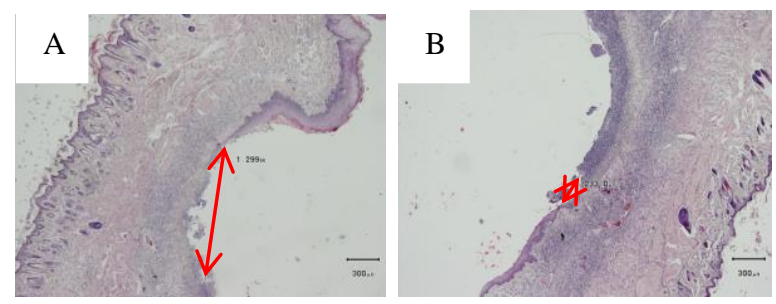

Gambar 7. Gambaran histologi reepitelisasi hari ke 6, dilakukan pengukuran lebar celah epitel dengan metode morfometri $(\mu \mathrm{m})$; A: Kelompok Kontrol; B: Kelompok Pemberian EGCG 0,5\%

Dalam penelitian ini, kerusakan epitel terjadi akibat trauma mekanis. Kerusakan jaringan menyebabkan pergerakan dan migrasi sel-sel epitel ke daerah luka. Pada awalnya, sel-sel epitel tersebut kehilangan perlekatannya dengan jaringan ikat dibawahnya. ${ }^{16}$ Regenerasi jaringan dimulai setelah fase inflamasi, pada awalnya terjadi regenerasi pada epitel kemudian jaringan ikat. Pada fase proliferasi terjadi reepitelisasi yaitu proses pembentukan kembali lapisan epitel yang rusak. $^{27}$ Monomer methacrylate akan melepaskan radikal bebas yang akan meningkatkan respon inflamasi sehingga menunda terjadinya migrasi dan proliferasi sel epitel. EGCG mampu menurunkan respon inflamasi dan meningkatkan faktor pertumbuhan yang diperlukan dalam reepitelisasi. ${ }^{21}$

Lebih lanjut, pemberian Epigallocatechin gallate (EGCG) yang merupakan senyawa polifenol menunjukkan efek antiinflamasi, antioksidan, serta memiliki potensi untuk meningkatkan penyembuhan luka melalui peningkatan kerja Transforming Growth Factor-beta 1 (TGF- $\beta 1){ }^{30}$ TGF- $\beta \quad 1$ menstimulasi migrasi dan meningkatkan kekuatan adhesi sel-sel epitel. $^{31}$ Katekin meningkatkan aktivitas enzim, menginduksi sintesis nitric oxide dan COX-2 yang diperlukan pada proses reepitelisasi luka. ${ }^{9}$

Pada penelitian ini, kelompok perlakuan EGCG
0,5\% memiliki lebar celah epitel yang lebih kecil dibandingkan kelompok kontrol (Gambar 7). Hal ini menunjukan bahwa reepitelisasi kelompok perlakuan lebih baik dibandingkan kelompok kontrol. Meningkatnya reepitelisasi ini dapat disebabkan oleh karena EGCG mampu meningkatkan penyembuhan luka dengan meningkatkan Transforming Growth Factorbeta 1 (TGF- $\beta 1$ ) yang menyebabkan peningkatan migrasi sel-sel epitel. Migrasi dan proliferasi sel-sel epitel ini akan berhenti ketika luka sudah tertutup sempurna.

Pada reepitelisasi, pembelahan sel dimulai di lapisan basal, kemudian sel-sel epitel dengan cepat saling berdekatan sehingga jarak antar tepi luka membentuk celah epitel yang lebih pendek. ${ }^{16}$ Sel-sel epitel di daerah tepi luka melepaskan perlekatannya dengan hemidesmosom dan memulai migrasi 24 jam pertama setelah luka. Proliferasi dimulai pada leading edge kemudian sel-sel epitel mulai menyebar ke daerah luka. ${ }^{31}$ Sel-sel epitel pada mukosa mulut terus bermigrasi sampai mencapai tepi luka sisi lainnya, pada proses reepitelisasi terjadi peningkatan pembelahan sel menyebabkan stratifikasi, diferensiasi, dan terbentuk jaringan epitel normal. $^{16}$

\section{SIMPULAN}

EGCG dapat meningkatkan reepitelisasi dalam penyembuhan luka mukosa mulut pada penderita Denture Stomatitis.

\section{DAFTAR PUSTAKA}

1. Emami E, De Grandmont PH. Favouring trauma as an etiological faktor in denture stomatitis. $J$ Dent Res 2008; 87(5): 440-4.

2. Naik AV, Pai RC. A study of faktors contributing to denture stomatitis in a North Indian Community. International Journal of Dentistry 2011; 11:1-4.

3. Pathmashri VP, Abirami. A Review on Denture Stomatitis. J Pharm Sci \& Res 2016; 8(8):875-877.

4. Greenwall L, Li Y. Safety Issues of Tooth Whitening Using Peroxide-Base Material. British Dental Journal 2013; 215(1): 29-34.

5. Lima MHM, Mahmoud JGE, Gaspareti AL, Parisi MC, Velloso LA. Ascorbic Acid For The Healing of Skin Wounds In Rats. Journal of Investigative Dermatology 2009; 103(2): 28-32.

6. Muchtadi D. Gizi Anti Penuaan Dini. Bandung: Alfabeta; 2009.

7. Lingga L. The Healing Power of Antioxidant. Jakarta: Elexmedia; 2012.

8. Forouzanfar A, Arab H, Shafaee H, Mokhtari M, and Golestani S. The effect of green tea mouthwash (Camellia sinensis) on wound healing following periodontal crown lengthening surgery; a double blind randomized kontrolled trial. Open Journal of Stomatology 2012; 2: 369-72.

9. Tsai TC, Hantash BM. Cosmeceutical Agents: A Comprehensive Review of the Literature. Clinical Medicine: Dermatology 2008; 1: 1-20.

10. Hajiaghaalipour F, Kanthimathi MS, Abdulla MA, dan Junedah S. The Effect of Camellia sinensis on Wound Healing Potential in an Animal Model. Evidence-Based Complementary and Alternative 
Medicine 2013; 7: 1-8.

11. Gaur A, KumarVG, Siddiqui SR, Agarwal S, Monga HS, Gosavi SS. Study of Prevalence of Oral Lesions in Complete Denture Wearers. J Int Oral Health 2015;7(11):97-100.

12. Gade J, Pawar VS, Singh N. Review on Denture Stomatitis: Classification, Clinical Features and Treatment. IOSR-JDMS 2015;14(12):114-22

13. Newton AV. Denture Sore Mouth A Possible Aetiology. Br Dent J 1962; 112: 357-63.

14. Avery JK, Chiego DJ. Essentials of Oral Histology And Embryology: A Clinical Aproach. 3 ed. St. Louis: Mosby Inc; 2006. p.177-83.

15. Balogh MB, Fehrenbach MJ. Dental Embryology, Histology, and Anatomy. Second Edition. Oak Park: Illinois; 2006. p.105-14.

16. Nanci A. Ten Cates Oral Histology: Development, Structure, and Function. St. Louis: Mosby Inc; 2008.

17. Delong L, Burkhart N. General and Oral Pathology for the Dental Hygienist. Edisi ke-2. Baltimore: Wolters Kluwer/Lippincott Williams \& Wilkins; 2013.

18. Gottrup F, Jensen SS, Andreasen JO. Wound Textbook and Color Atlas of Traumatik injuries to the teeth. In: Gottrup F, Jensen SS, Andreasen, JO. Healing Subssequent to Injury. Fourth Edition. Oxford: Blackwell Munksgaard; 2007. p.1-44.

19. Mackay D, Miller A.L. Nutrutional Support for Wound Healing. Alternative Medicine Review 2003; 8(4): 359-77.

20. Prasetyono TOH. General concept of wound healing. Med J Indonesia 2009; 18: 206-14.

21. Schultz GS. Surgical Wound Healing and Management. In: Granick MS, Gamelli RL. The Physiology of Wound Bed Preparation. Switzerland: Informa Healthcare; 2007. p. 1-16.

22. Winarsi H. Antioksidan Alami dan Radikal Bebas: Potensi dan Aplikasinya dalam Kesehatan. Yogyakarta: Kanisius; 2007. p.153.

23. Saryono. 2013. Potensi Teh Hijau dalam Penyembuhan Luka. Naskah Lengkap Konferensi Nasional PPNI Jawa tengah. p. 202-05.
24. Kim H, Kawazoe T, Han DW, Matsumara K, Suzuki S, Tsutsumi S and Hyon SH. Enhanced wound healing by an epigallocatechin gallateincorporated collagen sponge in diabetic mice. Wound Repair and Regeneration 2008; 16: 714 20. Available from: http://www.ncbi.nlm.nih.gov/ pubmed/19128267 Accessed feb 14, 2013.

25. Federer W.. Statistics and society: data collection and interpretation. Edisi ke-2. New York: Markel Deker; 2008.

26. Neves ALA, Komesu MC, Di Mateo MAS. Effects of Green Tea Use on Wound Healing. Int. J. Morphol 2010; 28(3): 905-10.

27. McKelvey K, Xue M, Whitmont K, Shen K, Cooper A, Jacson C. Potential anti-inflamatory treatments for chronic wounds. Wound practice and research 2012; 20(2): 86-9.

28. Asadi SY, Parsaei P, Karimi M, Ezzati S, Zamiri A, Mohammadizadeh F, Kopaei MR. Effect of green tea (Camellia sinensis) extract on healing process of surgical wounds in rat. International Journal of Surgery 2013; 11: 332-7.

29. Keller U, Kumin A, Braun S, Werner S.. Reactive Oxygen Species and Their Detoxification in Healing Skin Wounds. Journal of Investigative Dermatology Symposium Proceedings 2006; p.11.

30. Klass BR, Branford OA, Grobbelaar AO, Rolfe KJ. The effect of epigallocatechin-3-gallate, a constituent of green tea, on transforming growth faktor-beta1- stimulated wound contraction. Wound Repair Regeneretion 2010; 18(1):80-8

31. Larjava H. Oral Wound Healing: Cell Biology And Clinical Management. Oxford: John Wiley \& Sons; 2012. 